This Journal is available in Telkom University online Journals

Jurnal Manajemen Indonesia

\title{
Differences In Consumers' Attitude Towards Online Shops Based On Product Types And Consumer Characteristics And Their Influence On Repurchase Interests
}

\author{
Odilia Larasati Hertaswari ${ }^{1}$, Ike Janita Dewi ${ }^{2}$ \\ ${ }^{1,2}$ Management Study Program, Faculty of Economics, Sanata Dharma University, Yogyakarta, Indonesia
}

\begin{abstract}
The research responds to the new realities in marketing environment following the rapid development of internet and information technology. In accordance with Yadav and Pavlou's (2014) new research directions in computermediated environments, this research examines the relevance of market segmentation in online distribution strategies. Specifically, this research aims at analyzing: (1) the difference in consumers' attitudes towards online shops based on consumers' demographic and behavioral characteristics, (2) the difference in consumers' attitudes towards online shops depending on product type sold by the online shops, and (3) influence of attitude towards online shops on repurchase intentions. Data were collected using online and offline questionnaire to 200 respondents. Data analysis techniques include Analysis of Variance, multiple comparison, and simple linear regression. Results of the research show that demographic (gender and age) and behavioral (frequency of purchase) segmentation variables can generally explain differences in consumers' attitude towards online shops. Differences in consumers' attitudes are also shown in the cases of different product types (gadgets versus fashion) sold in the online shops. Lastly, consumers' attitudes positively affect repurchase intention.
\end{abstract}

Keywords-attitude; computer-mediated consumer behavior

\begin{abstract}
Abstrak
Penelitian ini merespon realitas baru dalam lingkungan pemasaran sekarang ini, pasca perkembangan pesar teknologi informasi dan internet. Sesuai dengan proposisi Yadav dan Pavlou (2014) tentang arah baru dalam lingkungan yang dimediasi internet, penelitian ini menganalisis relevansi konsep segmentasi pasar dalam lingkungan baru ini, khususnya dalam strategi distribusi secara daring yang difasilitasi internet. Secara spesifik, penelitian ini bertujuan untuk: (1) perbedaan dalam sikap konsumen terhadap toko daring berdasarkan karakteristik demografis dan keperilakuan konsumen, (2) perbedaan dalam sikap konsumen terhadap toko daring berdasarkan jenis produk yang dijual oleh toko daring tersebut, dan (3) pengaruh sikap terhadap toko daring pada minat beli ulang. Data diperoleh melalui kuesioner yang disebarikan secara luring dan daring kepada 200 responden. Teknik analisis data yang digunakan adalah ANOVA, multiple comparison, dan regresi linear sederhana. Hasil penelitian menunjukkan bahwa karakteristik demografis (jenis kelamin dan umur) dan karakteristik keperilakuan (frekuensi pembelian) konsumen secara umum bias menjelaskan perbedaan sikap konsumen terhadap toko daring. Perbedaan dalam sikap konsumen juga ditunjukkan dalam kasus perbedaan jenis produk (elektronik atau fesyen) yang dijual oleh toko daring tersebut. Penelitian ini juga menyimpulkan bahwa sikap konsumen berpengaruh positif pada niat beli ulang.
\end{abstract}

Kata kunci-sikap; perilaku konsumen dimediasi komputer 


\section{INTRODUCTION}

The development of information technology has brought changes in the world of commerce and especially in the retail industry. Online commerce is a business model where products are sold directly to business consumers or end consumers. As a global phenomenon, online trade growth recorded a growth of $20 \%$ and a sales turnover of US $\$ 1,845$ trillion in 2015 . This figure represents $7.4 \%$ of total world retail sales. The share of sales via the internet is expected to continue to grow to reach more than 15\% in 2020 (Dobreva, 2016). The growth of online trade in Indonesia even recorded the fastest growth rate in the world, where in 2013 there was a growth of $73 \%$ with sales figures of US \$ 1.8 billion (Kokubo, 2014). Indonesia's trade transactions reached IDR 25.1 trillion in 2014 and is estimated to reach IDR 69.8 trillion in 2016 (http://databpks.katadata.co.id).

The growth of online commerce that has given rise to online shops has implications for the formulation of marketing strategies. Yadav and Pavlou (2014) state that this new reality requires new directions in marketing research. Computer-mediated consumer behavior requires a new understanding of the concept of market segmentation, the level of product involvement, and consumer attitudes towards the new online retail platform.

In marketing theory, market segmentation is a strategic decision that is taken as the basis for determining target markets and formulating marketing strategies. As a marketing concept, market segmentation is one of the most established concepts, with the development of the basis of market division starting from demographics (for example: age and gender), geographic (eg rural-urban), psychographics (including self-concept and lifestyle), and behavior (which includes frequency of purchases, level of loyalty, etc.). These consumer characteristics will influence consumer attitudes and behavior (Hawkins, Motherbaugh, and Best, 2007; Kanuk, 2010). If in conventional marketing this research area has been widely explored, consumer responses based on these characteristics need a lot of research (Yadav and Pavlou, 2014).

Based on the background and significance of market segmentation studies in the context of online retail, this study aims to analyze: 1) differences in consumer attitudes towards online stores that sell electronic products (gadgets) in terms of consumer characteristics (i.e. gender, age, and frequency of purchases at online stores, 2) differences in consumer attitudes towards online stores that sell fashion in terms of consumer characteristics (namely gender, age, and frequency of purchases at online stores), and 3) the influence of consumer attitudes towards online stores on repurchase interest.

\section{LITERATURE REVIEW}

Kotler and Armstrong (2008: 225) state that market segmentation is one of the most important marketing strategies. Market segmentation involves dividing the market into smaller groups of buyers with different needs, characteristics, or behaviors that may require a separate product or marketing mix. Attitude is a description of evaluation, that is, where someone likes or dislikes an object (Fishbein and Azjen, 1975). Attitudes also represent consumers' perception of the benefits of an attitude object (Hartmann and Apaolazz Ibáñez, 2012).

Attitudes are formed as a result of direct experience about products, information from other people, or product advertisements in various media. A consumer will form an attitude towards a certain attitude object based on personal factors (individual characteristics) and stimuli characteristics (types of products as attitude objects). In this study, personal factors used were demographic segmentation variables, namely gender (male vs female), age (above and below 39 years) and the behavioral segmentation variable, namely the frequency of purchase. The characteristics of the stimuli used are the types of products sold in online stores, namely online stores that sell gadgets and online stores that sell fashion.

Consumer attitudes which are dispositions or feelings of like/ dislike towards certain types of products can be formed because of the gender of the consumer. In market segmentation, gender is a predictor that results in different attitudes and behaviors (Melnyk, van Osselaer, and Bijmolt, 2009). The formation of consumer attitudes towards online shopping activities (e-commerce) has been widely studied using various theoretical frameworks such as Theory of Planned Behavior (Han and Kim, 2018) or a model of consumer behavior that is constructed based on the experience of surfing in cyberspace (web experience) (Ricahard, et al., 2010).

In body of research on consumer behavior in online purchases, demographic characteristics of consumers are often used as predictors or factors that determine differences in consumer behavior (Hernández, Jiménez, and Martin, 2010; Rodgers and Harris, 2003). Specifically, the study of Rodgers and Harris (2003) states that gender is an important factor in studying consumer behavior. This study argues that different attitudes will be shown by different gender depending on the type of products sold by the online shop. Several articles also mention that in 
terms of shopping for complementary gadgets or accessories, in general men tend to be more consumptive than women. Men tend to spend more money on gadgets and other electronic products (Anderson and Iskandar, 2014). In addition, based on the observations of researchers, in several groups buying and selling gadgets online on Facebook, such as the "Handphone and Jogja" and "Jogja City Mobile Selling and Purchasing" groups and other groups, the number of group members (members) who are male is far more than that of woman.

Meanwhile, women's more positive attitudes towards online stores can also be shaped by the types of products sold at these online stores. Hansen and Møller (2009) and Hernández, Jiménez, and Martin (2010) state that there are differences in fashion shopping behavior in terms of gender. Women tend to be more consumptive than men when it comes to fashion. Women tend to buy clothes in greater quantity than men. Women are more interested in products related to lifestyle, beauty and fashion. Men are more likely to buy only the fashion products they need (Anderson and Iskandar, 2014).

Based on these arguments, this research proposes Hypothesis 1a and Hypothesis $1 \mathrm{~b}$ as follows.

$\mathrm{H}_{1 \mathrm{a}}$ : There are differences in consumer attitudes towards online stores that sell gedgets in terms of consumer gender, where male consumers have a more positive attitude than female consumers.

$\mathrm{H}_{1 \mathrm{~b}}$ : There are differences in consumer attitudes towards online stores that sell fashion in terms of consumer gender, where female consumers have a more positive attitude than male consumers.

Apart from gender, another basis for demographic segmentation, namely age (or generation), can also explain differences in consumer attitudes and behavior. Hernández, Jiménez, and Martin (2010) and Scorce and Widrick (2005) specifically mention the age is a predictor of online shopping behavior, where younger ages are more likely to be technology literate. Segmentation which is based on generation identifies Generation Y or Millennial segment born between 1977-1997 (Tapscott, 2009: 23) to be more technology-savvy. This generation was born and grew up with the era of sophisticated and widely available technology. With such an environment, Generation $\mathrm{Y}$ which is very technology-oriented, quickly adopts new technology, and makes technology a part of their daily life. Therefore, the millennial generation (who are less than 39 years old) will have a more positive attitude towards online stores, both for the gadget and fashion product categories.

Based on these arguments, this research proposes Hypotheses $2 \mathrm{a}$ and $\mathrm{H}_{2 \mathrm{~b}}$ as follows.

$\mathrm{H}_{2 \mathrm{a}}$ : There is a difference in consumer attitudes towards online stores that sell gadgets in terms of consumer age, where younger consumers ( $\leq 39$ years) have a more positive attitude than older people ( $>39$ years).

$\mathrm{H}_{2 \mathrm{~b}}$ : There is a difference in consumer attitudes towards online stores that sell fashion from the age of the consumers, where younger consumers ( $\leq 39$ years) have a more positive attitude than older people (> 39 years).

Characteristics of consumer behavior (behavioral segmentation) is also a relevant segmentation variable used as an explanation for differences in consumer attitudes and behavior. In this study, the behavioral segmentation variable used is frequency of purchase. As noted earlier, a person's attitude is also shaped by their previous online purchasing experience and the level of adoption of this new technology. The frequency of purchases will result in a more experienced consumer. As stated by Kumaga and Nagasawa (2015) and Monteiro and Giuliani (2017), consumer practice will result in a more positive attitude. Therefore, the higher frequency of using this online shopping mode will result in a more positive attitude, especially since the technology barrier is reduced/ no longer exists. These habitual factors tend to be general or not limited to certain product categories. Therefore, this research proposes Hypotheses $\mathrm{H}_{3 \mathrm{a}}$ and $\mathrm{H}_{3 \mathrm{~b}}$ as follows.

$\mathrm{H}_{3 \mathrm{a}}$ : There is a difference in the attitude of consumers towards online stores that sell gadgets from the behavioral aspect, where consumers who have a higher frequency of buying online have a more positive attitude than those who buy less frequently. 
$\mathrm{H}_{3 \mathrm{~b}}$ : There is a difference in Consumer Attitudes towards Online Stores that sell fashion from the behavioral aspect, where consumers who have a higher frequency of buying online have a more positive attitude than those who buy less frequently.

Apart from the attitude aspect, the study of consumer behavior also focuses on the behavioral aspect. Aspects of this behavior can be an interest in buying or an interest in repurchasing. Purchase interest is a person's tendency to buy a product before someone has actually made a decision to buy. In other words, purchase interest is a plan to buy a product and has the possibility that consumers will make a purchase. A marketer must know the consumer's purchase intention of a product to predict consumer interest in the future, so that marketers can continue to develop their marketing strategies effectively.

If attitude is more of a person's internal evaluation of a certain object, the study of consumer behavior is interested in the strength of attitude as a predictor of behavior. This means that attitudes affect behavior intentions or even the behavior itself. A positive attitude towards a certain object will also result in a tendency to behave in a certain way (Azjen and Fishbein, 2005; Han and Kim, 2018; Hartmann and Ibáñez, 2012; Hawkins and Mothersbough, 2007; Richard et al, 2010). If consumers have a positive attitude towards online stores, they are more likely to make purchases or repurchases at online stores. Based on these arguments, the researchers propose $\mathrm{H}_{4}$ as follows.

$\mathrm{H}_{4}$ : Attitudes towards Online Shops influences positively Repurchase Interest.

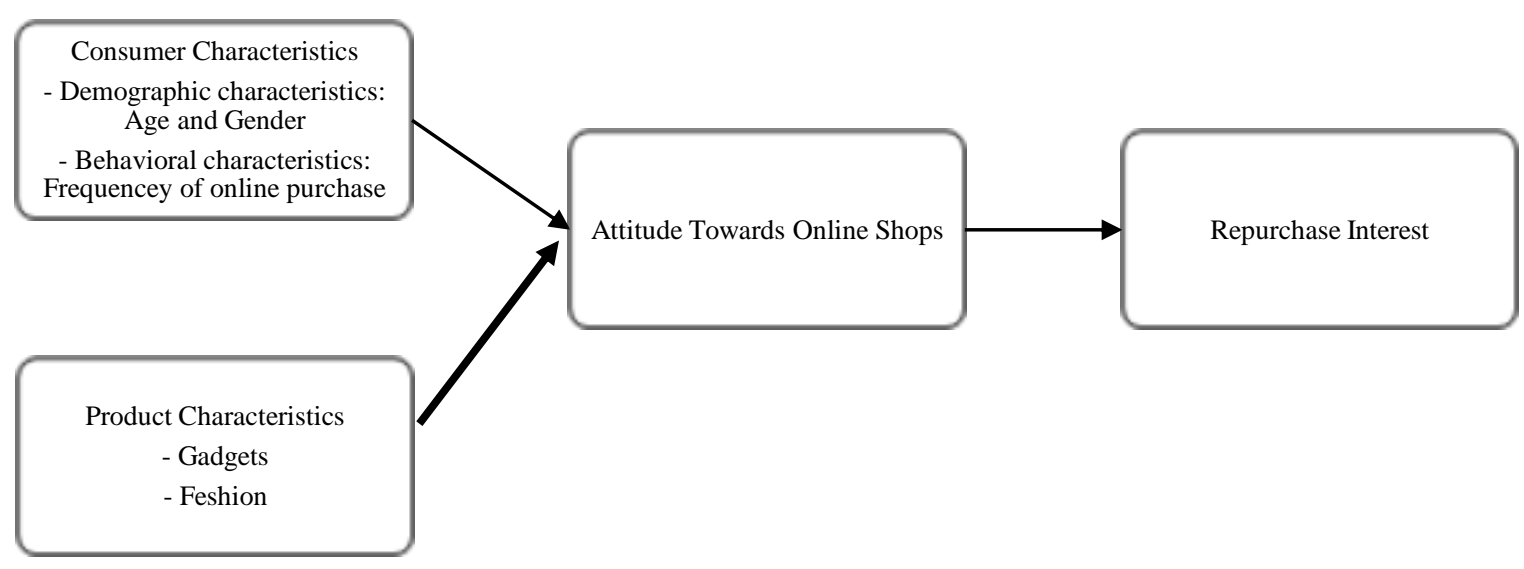

Figure 1. Research Conceptual Framework (adapted from various sources) 


\section{RESEARCH METHODS}

This research is a quantitative study that tests the hypothesis. In terms of the time dimension, this study is a cross-sectionial study because it is carried out only at a certain period of time. The population of this study is all consumers who have made purchases online, namely in online gadget or fashion online stores. The sample in this study was as many as 100 people for each type of online stores, with a between-subjects design (which means that a sample member only fills in one type of online store). Samples were taken by non-probability, using purposive sampling technique. The criteria applied are consumers who have purchased at an online gadget/ fashion store in the last 3 (three) months. The data analyzed is primary data collected through questionnaires distributed to respondents online (using google form) and also offline.

Variable measurements are carried out by referring to the conceptual definition of variables and adaptation of measurements that have been used in other studies (Ajzen and Fishbein, 2005; Cheah, Phau, and Liang, 2015). Attitudes towards online shops are operationalized using 5 (five) items (note: in the questionnaire, the terminology is still used in English considering the popularity of the terminology): 1) I like online shops that sell gadgets/ fashion, 2) I believe in online shops that sell gadgets/ fashion, 3) I feel enthusiastic about the idea of shopping for gadgets/ fashion through online shops, 4) Gadgets/ fashion online shops are credible shopping places, 5) I feel happy shopping for gadgets/ fashion in online shops. Repurchase interest is operationalized using 5 (five) statements: 1) I will return to using gadget/ fashion online shops to meet my needs, 2) I will return to shopping for gadget/ fashion through online shops, 3) I will recommend to friends/ family to shop for gadgets/ fashion in online shops, 4) I will provide information about gadget / online fashion shops to other people, 5) I will continue to seek information about shopping for gadget / fashion in online shops. The scale used is a Likert scale with a range of 1 (strongly disagree) to 5 (strongly agree).

The instrument was tested for its validity and reliability. The validity test was conducted using Pearson's product moment correlation while the reliability test was conducting employing Cronbach's alpha. The data analysis techniques to answer the research objectives number 1-3 were Analysis of Variance and Bonferroni's post-hoc to test the mean differences between the two groups (multiple comparisons). For the fourth research question, a simple linear regression analysis was used with the independent variable (X) Attitudes towards Online Stores and the dependent variable (Y) Repurchase Interest. As a prerequisite for regression analysis, a classic assumption test, which includes a normality test and a heteroscedasticity test, was carried-out.

\section{RESUlT AND DisCUSSION}

Of the 220 collected questionnaires, 200 questionnaires could be further processed because the data was complete and the respondents met the criteria as members of the sample. To ensure the fulfillment of these criteria, the questionnaire includes a screening question, namely: "Have you ever purchased goods online within the last 3 months?". The profiles of respondents are presented in Table 1. The test of the instrument fulfills the requirements in the validity and reliability test. All items in the instrument are valid and reliable so that the average value of respondents' answers for these items/ variables can be used. The average score for each item and variable is presented in Table 2 .

Table 2 shows the respondent's profile which of the 100 respondents is for an online store that sells gadgets and 100 respondents for an online store that sells fashion. Respondents are distributed in each group tested, namely in terms of gender, age, and frequency of online shopping. 
Table 2. Respondents' Profile

\begin{tabular}{|c|c|c|}
\hline \multirow[b]{2}{*}{ Description } & \multicolumn{2}{|c|}{ Number of Respondent } \\
\hline & $\begin{array}{c}\text { Gadget } \\
\text { online shop }\end{array}$ & $\begin{array}{c}\text { Fashion online } \\
\text { shop }\end{array}$ \\
\hline \multicolumn{3}{|l|}{ Gender } \\
\hline Male & 53 & 46 \\
\hline Female & 47 & 54 \\
\hline \multicolumn{3}{|l|}{ Age } \\
\hline$\leq 39$ years old & 58 & 56 \\
\hline$>39$ yearks old & 42 & 44 \\
\hline \multicolumn{3}{|l|}{ Frequency of shopping online (in the past year) } \\
\hline$>12$ times & 35 & 29 \\
\hline 5-12 times & 34 & 27 \\
\hline$<5$ times Frequency of shopping online (in the past year) & 31 & 44 \\
\hline \multicolumn{3}{|l|}{ Amount of money spent per online shop (IDR) } \\
\hline$<100.000$ & 34 & 36 \\
\hline $100.000-500.000$ & 41 & \\
\hline $501.000-1.000 .000$ & 19 & 42 \\
\hline$>1.000 .000$ & 0 & 18 \\
\hline & & 4 \\
\hline
\end{tabular}

Source: Primary Data (processed)

The responses for each item in the questionnaire are presented in Table 3. The average score for Attitudes towards Gadget Online Stores is 3.20 and Attitudes towards Fashion Stores is 3.40. Meanwhile, the average scores for Repurchase Interest at Online Stores Selling Gadget and Fashion were 3.26 and 3.43, respectively.

Table 2: Descriptive Statistics: Mean Scores of Responses for Each Item/ Variable

\begin{tabular}{clcc}
\hline Item & Indicator & $\begin{array}{c}\text { Mean score } \\
\text { for Online } \\
\text { Shops selling } \\
\text { Gadgets }\end{array}$ & $\begin{array}{c}\text { Mean Score } \\
\text { for Online } \\
\text { Fashion } \\
\text { ATTITUDES TOWARD ONLINE SHOPS }\end{array}$ \\
\hline 1 & Happy with online shops & 3.37 & 3.48 \\
\hline 2 & Trust online shops & 3.26 & 3.64 \\
\hline 3 & Excited about the idea of shopping through an online shop & 3.15 & 3.37 \\
\hline 4 & Online shops are credible shopping places & 3.14 & 3.16 \\
\hline 5 & Enjoy shopping at online shops & 3.08 & 3.40 \\
\hline
\end{tabular}




\begin{tabular}{clcc}
\hline \multicolumn{2}{l}{ REPURCHASE INTEREST } & & \\
\hline $1 . \quad$ Will return to using online shops to meet needs & 3.00 & 3.16 \\
\hline $2 . \quad$ Will return to shopping via online shops, & 2.91 & 3.22 \\
\hline $3 . \quad$ Will recommend to friends/ family to shop at online shops & 3.34 & 3.52 \\
\hline $4 . \quad$ Will provide information about online shops to others & 3.33 & 3.85 \\
\hline $5 . \quad$ Will continue to search for information about shopping in & 3.74 & 3.43 \\
\hline & online shops & & 3.26 \\
\hline
\end{tabular}

Source: Primary data (processed)

If divided by group, the average score for each group is as follows (Table 3). The average score of consumer attitudes towards online stores selling devices based on gender is 3.4670 (for men) and 2.9628 (for women). The difference test on the average score in the two groups was significant $(p \leq 0.01)$, where the score for male respondents' Consumer Attitudes was higher. Thus $\mathrm{H}_{1 \mathrm{a}}$ is supported. For online stores that sell fashion, the average score for the female respondent group is higher than the average score for men. The difference is statistically significant $(\mathrm{p} \leq 0.01)$ so $\mathrm{H}_{1 b}$ is supported. The results of this study support the concept of demographic segmentation, where consumer gender can be a factor that differentiates consumer responses to certain marketing stimuli (Kotler and Keller, 2012). However, this research shows that the different responses are depended on the type of product (gadget/ fashion). So, in line with the research of Cunningham and Roberts (2006), gender as a factor explaining differences in consumer responses is not generally applicable. Differences in male vs female attitude will also depend on the type of product. Women will have more positive attitude for product categories that are liked by women, while men will have a more positive attitude towards products that are liked by men.

Table 3: Mean Scores of Consumer Attitudes by Gender

\begin{tabular}{lccc}
\hline & Male & Female & Mean Difference \\
\hline Online Shops That Sell Gadgets & 3.4670 & 2.9628 & $\left.0.5042^{* * *}\right)$ \\
\hline Online Shops That Sell Fashion & 3.1261 & 3.6963 & $\left.-0.5702^{* * *}\right)$
\end{tabular}

Notes:

$* * *)$ significant at $\mathrm{p} \leq 0,01 ; * *)$ significant at $\mathrm{p} \leq 0,05 ; *)$ significant at $\mathrm{p} \leq 0,1$

Table 4 shows the results of the analysis of differences in consumer attitudes based on age. For online stores that sell gadgets, there is no difference in the mean score of Consumer Attitude based on age groups. Result shows that the mean score of attitude of consumers aged> 39 years is higher, but the mean difference is not significant. Thus, Hypothesis 2a is not supported. This result means that in terms of purchasing a device, age difference cannot be a factor explaining differences in consumer attitudes. During its development, online sales have been dominated by electronic products, including gadgets. The characteristics of standardized gadgets and their particular brands make comparison of prices and features in online shops are very easy to undertake. Therefore, all age groups tend to like shopping for gadgets online. This suggests that findings of empirical research on Indonesian consumers in online shopping behavior can be different compared to those from other countries' (Hansen and Møller, 2009). 
For fashion, age can explain the differences in consumer attitudes towards online stores. The attitude of consumers aged $\leq 39$ years old was significantly more positive $(\mathrm{p} \leq 0.01)$ than those aged $>39$ years old. Therefore, Hypothesis $2 b$ is supported. So consumer characteristic in terms of age can explain differences in consumer attitudes towards fashion stores. The differences in results for gadgets and fashion indicate that age of consumers and types of product will interact in explaining consumer attitudes. In other words, age will explain consumer response to online stores depending on the type of product sold by the online store. This is in line with findings from the studies of Hansen and Møller (2009) and Sorce, Widrick, and Perotti (2005).

Table 4: Mean Scores of Consumer Attitudes by Age

\begin{tabular}{lccc}
\hline & $\leq 39$ years old & $>39$ years old & Mean Difference \\
\hline Online Stores That Sell Gadgets & 3.4261 & 3.6963 & $0.2702^{\text {n.s) }}$ \\
\hline Online Stores That Sell Fashion & 3.6643 & 3.1409 & $0.5234 * * *)$ \\
\hline
\end{tabular}

Notes:

$* * *)$ significant at $\mathrm{p} \leq 0,01 ; * *)$ significant at $\mathrm{p} \leq 0,05 ; *)$ significant at $\mathrm{p} \leq 0,1 ; \mathrm{n} . \mathrm{s}=$ not significant

The results of the post-hoc Bonferroni multiple comparison analysis to examine differences in attitudes towards online stores (gadgets/ fashion) show that in general there are significant differences between groups of respondents who shop online less frequently than those who shop more frequently. However, when viewed in detail per group, for online stores selling fashion, the mean score of attitudes did not differ significantly between groups of respondents who bought with a frequency of $<5$ times by buying between 5-12 times. Likewise, for online stores that sell gadgets, there was a marginal difference $(\mathrm{p} \leq 0.1)$ between groups that bought with a frequency of 5-12 times and those who bought $>12$ times (see Table 5). Based on the results of the meandifference test, Hypotheses $3 \mathrm{a}$ and $3 \mathrm{~b}$ are generally supported. These results are consistent with Kotler and Keller (2012), Kumaga and Nagasawa (2015) and Monteiro and Giuliani (2017) who state that one of the factors that determine consumer attitudes is behavioral characteristic of consumers. Consumers who buy or use certain products more often form expertise in accessing/ using the product and eventually develop a more positive attitude towards the product.

Table 5: Mean Scores of Consumer Attitudes Based on Frequency of Online Purchases

\begin{tabular}{lcc}
\hline \multirow{2}{*}{$\begin{array}{c}\text { Frequency of Online Purchases } \\
\text { (per year) }\end{array}$} & \multicolumn{2}{c}{ Difference in Mean Score of Attitudes } \\
\cline { 2 - 3 } & Online Stores That Sell Gadgets & Online Stores That Sell Fashion \\
\hline $\begin{array}{l}\text { Frequency }<5 \text { times } \\
\text { à-vis } 5-12 \text { times }\end{array}$ & $-0.52277^{* * *)}$ & $-0.30286^{\text {n.s) }}$ \\
\hline $\begin{array}{l}\text { Frequency }<5 \text { times } \\
\text { vis-à-vis }>12 \text { times }\end{array}$ & $-0.88664 * * *)$ & $-0.85408^{* * *)}$ \\
\hline $\begin{array}{l}\text { Frequency 5-12 times } \\
\text { vis-à-vis }>12 \text { times }\end{array}$ & $\left.-0.36387^{*}\right)$ & $-0.55121^{* * *)}$ \\
\hline $\begin{array}{l}\text { Notes: } \\
* * *)\end{array}$ significant at $\left.\mathrm{p} \leq 0,01 ; * *\right)$ & significant at $\mathrm{p} \leq 0,05 ; *)$ & \\
\end{tabular}

The results of the regression analysis for the effect of attitudes towards online stores selling gadgets on repurchase interest show a significant positive effect (regression equation: $\mathrm{Y}=1.639+0.503 \mathrm{X} * *$ ). Likewise, the attitudes towards online stores selling fashion influences repurchase interest, where the effect is positive and significant (regression equation: $\mathrm{Y}=1.142+0.673 \mathrm{X} * *$ ). Based on this regression analysis, Hypothesis 4 is 
supported. The results of this study are consistent with Azjen and Fishbein (2005) and Hawkins, Motherbaugh, and Best (2007) who state that attitude is a predictor of behavior. Someone who likes a certain product (i.e., having a positive attitude towards a product) will have a tendency to buy that product.

\section{CONCLUSSION}

This study results in the following conclusions. In examining the gender factor in shaping attitudes towards online stores with certain product categories, it can be concluded that: 1) there are differences in attitudes towards online stores that sell gadgets in terms of gender, where men have more positive attitudes; 2) there are differences in attitudes towards online shops that sell fashion based on gender, where women have more positive attitude. In terms of examining the 'age factors' in explaining consumers' attitude: 1) age does not explain differences in attitudes towards online stores selling gadgetss (there is no difference in attitudes of consumers aged $\leq 39$ years compared to those aged $>39$ years), 2) however, age explain sdifferences in attitudes towards online stores selling fashion products, where consumers aged $\leq 39$ years have a more positive attitude. From the behavioral aspect, the frequency of purchases through online stores can explain the difference in consumer attitudes towards online stores that sell gadgets and fashion, where consumers who buy more often are more likely to be have more positive attitudes. This study also concluded that attitude can be a predictor of behavior because attitudes toward online stores have a positive effect on repurchase interest.

Managerially, the results of this study are useful in formulating marketing policies by re-emphasizing the importance of studying consumer market segmentation. This is important because consumer characteristics will produce different attitudes and behaviors. Online sales generally target a younger group of consumers. While male and female segments are potential target markets, marketers must be more sensitive to the product categories aimed at their respective segment groups. For example, an online store that sells a type of product aimed at the male segment should choose designs, attractions, product promos, etc. that are relevant to male consumers. On the other hand, online stores selling products targeted at female consumers also need to design and offer product promotions that appeal to female consumers. This research also shows the importance of behavioral aspects because the habit of using a product will result in a more positive attitude. Managers need to design incentives aimed at consumers to try (i.e, incentives to trial), for example by providing gift promos for first-time users or attractive discounts for consumers shopping for the first time at a certain online store. The formation of a positive attitude towards online stores is very important for managers to pay attention to because it will generate repurchase interest.

For further research, various other consumer characteristics, for example in terms of psychographics which include the level of consumer innovativeness and consumer self-concept, and from geographical aspects such as urban-rural areas, can be factors to be studied. Furthermore, stimulus aspects such as product types, promotions, prices, online store designs, etc. can also be factors to be studied. Other external factors, such as the strength of the reference group, could also further explain the differences in consumer attitudes towards online stores. Finally, methodically, the research design for further research needs to analyze the interactions between these factors, so that a factorial research can be designed with design 2 (product type: gadget vs fashion) x 2 (gender: male vs female) x 2 (age: young vs old) x 3 (behavior: rare vs moderate vs frequent) which will result in 24 sub-groups. Apart from being able to examine the interactions between these factors, such research design will involve more sample members.

\section{REFERENCES}

Ajzen, Icek dan Fishbein, Martin (2005) 'The Influence of Attitudes on Behavior' dalam D. Albarracín, B. T. Johnson, M. P. Zanna (Eds), The Handbook of Attitudes, Mahwah, Lawrence Erlbaum Associates, New Jersey, pp 173-221.

Anderson, Ricky and Rezki Apriliya Iskandar. (2014) 'Perbedaan Cara Pandang Pria-Wanita Soal Belanja'. http://m.life.viva.co.id/news/read/547997-perbedaan-cara-pandang-pria-wanita-soal-belanja \{Diakses 8 Februari 2016).

Cheah, Isaac, Phau, Ian, and Liang, Johan (2015) 'Factors influencing consumers' attitudes and purchase intentions of e-deals', Marketing Intelligence \& Planning, Vol. 33 No. 5, pp. 763-783. 
Cunningham, Jane and Roberts, Phillipa (2006) 'What Woman Want', Brand Strategy, Dec 2006-Jan 2007, pp. 40-41.

Dobreva, Ksenia (2016) Global E-commerce Trends and Statistics. http://amasty.com/blog/global-e-commercetrends-and-statistics/. (diakses 16 Feburari 2016).

Fisbein, Martin. and Ajzen, Icek (1975) Belief, Attitude, Intention and Behavior: An Introduction to Theory and

Research, Addison-Wiley Publishing Company, Boston.

Han Bangwool and Kim Minho (2018) 'Exploring Consumer Attitudes and Purchasing Intentions of Cross-Border Online Shopping in Korea'. Journal of Korea Trade, Vol. 22, No. 2, pp. 86-104.

Hansen, T. and Møller Jensen, J. (2009), "Shopping orientation and online clothing purchases: the role of gender and purchase situation", European Journal of Marketing, Vol. 43 No. 9/10, pp. 1154-1170.

Hartmann, Patrick and Apaolaza-Ibáñez, Vanessa (2012) 'Consumer Attitude and Purchase Intention Toward Green Energy Brands: The Roles of Psychological Benefits and Environmental Concern'. Journal of Business Research, Vol. 65, pp. 1254-1263.

Hawkins, Del. I, Motherbaugh. David L., and Best, Roger J. (2007) Consumer Behavior: Building Marketing Strategy, Edisi 10, McGraw-Hill Irwin, Boston.

Hernández, Blanca, Jiménez, Julio, and Martı̃̃ M. José (2011) 'Age, Gender and Income: Do They Really Moderate Online Shopping Behaviour?'. Online Information Review, Vol. 35, No. 1, pp. 113-133.

Kokubo, Taketo. (2014) 'Pelopor Belanja Grosir Bulanan Online’ Majalah Marketing, Edisi 09/XIV/September, pp 12-13.

Kotler, Philip and Amstrong, Gary (2013) Principles of Marketing, Edisi 15, Prentice Hall, Singapore.

Kotler, Philip and Keller, Kevin Lane (2012). Marketing Management, Edisi 14, Pearson, Singapore.

Kumagai, Ken and Nagasawa, Shin'ya (2015) 'Customer Experience and Determinants of Consumer Attitude Toward Luxury Brands: Observations in Japan and China’. Science Journal of Business and Management, Vol. 3. (2-1), pp. 24-34.

Schiffman, Leon G and Kanuk, Leslie Lazar (2010). Consumer Behavior, Edisi 10, Prentice Hall, New Jersey.

Liz C. Wang, Baker, Julie, Wagner, Judy A. and Wakefield, Kirk (2007) 'Can a Retail Web be Social'. Journal of Marketing, Vol. 71, No. 3, pp. 143-157

Melnyk, Valentina, van Osselaer, Stjin M. J., and Bijmolt, Tammo H.A. (2009) 'Are Women More Loyal Customers Than Man? Gender Differences in Loyalty to Firms and Individual Service Providers'. Journal of Marketing, Vol. 73 (July), pp. 82-96.

Monteiro,Thel Augusto and Giuliani, Antonio Carlos (2017) 'Consumer's Attitude, Innovation, Involvement and Experience in Digital World'. European Journal of Scientific Research, Vol. 147, No 4 (November), pp. 389-402.

Richard, Marie-Odile, Chebat, Jean-Charles, Yang, Zhiyong, and Putrevu, Sanjay (2010) 'A Proposed Model of Online Consumer Behavior: Assessing The Role of Gender’. Journal of Business Research, Vol. 63, pp 926-934.

Rodgers, Shelly and Harris, Mary Ann (2003) 'Gender and E-Commerce: An Exploratory Study'. Journal of Advertising Research, September, pp. 322-329.

Sorce, Patricia, Widrick, Stanley, and Perotti, Victor (2005) 'Attitude and Age Differences in Online Buying'. International Journal of Retail \& Distribution Management, February, pp. 122-132.

Tapscott, Don. (terj. Fajarianto) (2009) Grown Up Digital (Yang Muda Yang Mengubah Dunia). Gramedia, Jakarta.

Yadav, S. Manjit and Pavlou, Paul A. (2014) 'Marketing in Computer-Mediated Environments: Research Synthesis and New Directions'. Journal of Marketing, Vol. 78, No. 1, pp. 20-40.

---- (2016) 'Transaksi E-Commerce Indonesia naik 500\% dalam 5 tahun', http://databoks.katadata.co.id (Diakses pada 08 Februari 2016). 